\title{
A Qur'anic Approach to Family Institution: A Textual Study
}

\author{
${ }^{a}$ Bilal Hussain, ${ }^{b}$ Hafiz Mohsin Zia Qazi, ${ }^{c}$ Abdul Hamid, ${ }^{d}$ Numaira Altaf \\ ${ }^{a}$ Research Investigator Law, Council of Islamic Ideology, Islamabad, Pakistan \\ Email: dlaw@cii.gov.pk \\ ${ }^{\mathrm{b}}$ HOD Islamic Studies AMBLEM Education System Rawalpindi, Pakistan \\ ${ }^{\mathrm{c}}$ LT.CDR(R) Pakistan Navy, Lecturer Department of Islamic Studies, Bahria University Islamabad, Pakistan \\ ${ }^{\mathrm{d}}$ Government College University Faisalabad, Pakistan
}

\begin{tabular}{l}
\hline ARTICLE DETAILS \\
\hline History: \\
Accepted o6 June 2021 \\
Available Online June 2021 \\
\hline Keywords: \\
Family, Society, Islam, Qur'an, \\
Marriage, Divorce \\
JEL Classification: \\
J13, \\
\hline
\end{tabular}

DOI: $10.47067 /$ real.v4i2.170

\begin{abstract}
Contemporary state and society is evolved shape of family unit. All societies deeply respected this fundamental brick in the course of human civilization. Particularly, Muslim society has completely different ideology and structure regarding family. After individual, this divinely inspired institution has a prominent place in Muslim society. Quranic Studies being basic source of Islamic injunctions granted detailed regulations of this unit. It stated minutely rights and duties of family members to achieve its preliminary communal objective. All human civilizations recognized the marriage as established form of human relationship based on human instincts. Islam denied so-called heaven and unbroken status of marriage but introduced a mediated application of law. It is hour to study Islamic ideal concept of marriage and divorce especially in qur'anic debate. The study in hand will explore the status of family institution in Muslim society. It will highlight the eligibility of marriage, maintenance, gender equality and dower matters. This paper will provide some suggestions for further modifications in matrimonial laws of Pakistan. It will pave the way to better understand the legal aspect of family in Quranic verses.
\end{abstract}

(C) 2021 The authors. Published by SPCRD Global Publishing. This is an open access article under the Creative Commons AttributionNonCommercial 4.0

Corresponding author's email address: dlaw@cii.gov.pk

\section{Introduction}

Man as social human has much sensitivity and delicacy at his basic social unit, family. This root is as old as the birth of human. Indeed, family institution is first brick of human society as endorsed by all historical, religious and social studies. Ancient Greek, Roman, Arab, and Sub-continent city-states and small dynasties were relied on tribal structure expanded from families. Contemporary society is its evolved shape securing human's rights. Ancient era practiced various ideologies regulating institution of family but neglecting or giving inferior status of women in society (Ghazi, 2003). A human family has various objectives instead of offspring. It has permanent social, cultural and legal responsibilities. It is referred nursery for schooling of new generation. Truly, objectives of human creation can be achieved 
only through family institution. It is not just a civil contract but has legal, judicial and spiritual nature. Besides, it has deep psychological and sensitive touch also. Indeed, a government has very exceptional role in worship matters but supervising matrimonial justice is its fundamental responsibility.

Family, the smallest social unit, has enjoyed a prominent place in the course of human civilization. It is denoted a human social group bound by the blood ties and marital relationship. Normally, family term includes spouses, parents, children and siblings but here is intended only rights and duties of the first. Today, contemporary society has atmosphere of cultural crisis and its most sensitive institution, family, is being alarming from within and without (Bell, 1974). It is disintegrating and warn to re-examine the grounds on which family institution structured. This came into being with the creation of human not evolved through experiments like other social institutions. But it is divinely inspired and ordained one (Rahman, 2007). Human rights, gender equality and future saving other slogans birthed various social evils. Certainly, Muslim Society is completely distinct from others in its ideology and structure. After individual, Muslim society pays much attention on family institution. Certainly, a civilized society requires ideal family as individual one. This institution prepares ideal individuals according to spirit of Islam. Establishment of Muslim society is preliminary communal objective of Islam. Islam states detailed rights and duties of family members. This chapter presented the Islamic approach to the family institution particularly in the texts of the Holy Qur'an. It further denoted the verses regulating matrimonial matters. Moreover, it highlighted the pure sourced scripts for family, gender equality and women empowerment.

The Holy Qur'an holds a set of verses on family institution and marital matters even revealed a complete chapter with title of "Women". There are six permanent chapters expounding on marital matters; Baqra (Cow), Nisa (Women), Noor (Light), Ahzab (Congregation), Talaq (Divorce), and Tahrim (Prohibition). The most fundamental source of Islam, the Holy Quran, has more than one third instructions on family matters. Such detailed description on creation, nature and ethical manners of family institution, denotes its significant position in Muslim society.

Some vital verses related to creation and maintaining this institution are as under;

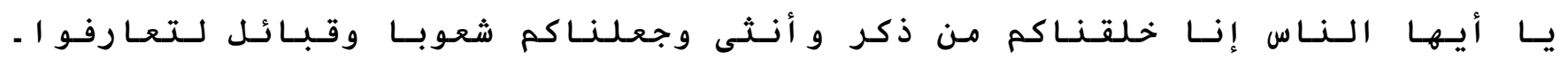

"O Peope! We created you from male and female (two genders) and classified into peoples and tribes for the purpose of your identification." Quran, 49:13)

At another verse;

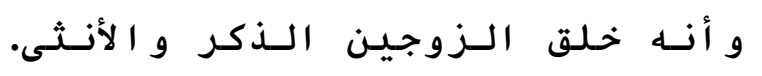

“And that He (God) created two genders, male and female.” (Quran, 53:45)

These verses clearly defined the family which is constituted by two distinct genders male and female (Qurtabi, 2012). Its revelation highlighted the basic kufuw (equity) between genders (Baghwi, 2019, ibn e kaseer, 2021). The Quran denied the western concept of unisex family. Family defined under Beijing plus Conference1994-5 or CEDAW1979, is totally unhuman and illegal (Rahman, 2007). Family institution is established only by two distinct genders, male and female not otherwise (Ibn e Ashur, 2020). These verses clearly descripted the evolution of society from family institution. They denoted fundamentals of social structure and civilization of Muslim society (Qutb, 2015). 
The holy text highlighted the nature of family. It is matter of fact that male is referred to family head and manager of all matrimonial affairs. Obviously, patrifocal family has encouraged on matrifocal one (Rahman, 2007). Moreover, rights and duties of family members and their safety is a collective responsibility. It includes their all types of betterment comprising of religious and world matters both (Al-Shawkani, 2013). The revelation is;

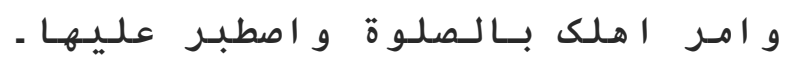

"And say your family to offer prayer and adhere to it strictly."( Quran, 20:132).

Another verse is;

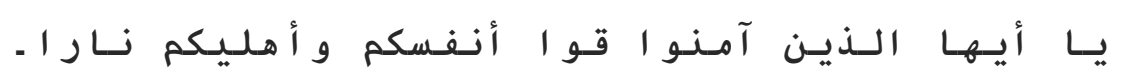

" O believers! Make safe yourselves and your families from a fire.” (Quran, 66:6).

Pre-Islamic society didn't grant woman the most fundamental human rights even the right to life in human society, Islam introduced the gender equality referring to the simultaneous creation of humanity by God. Both genders were leveled to equal status regarding basic rights and responsibilities. The Qur'an said as;

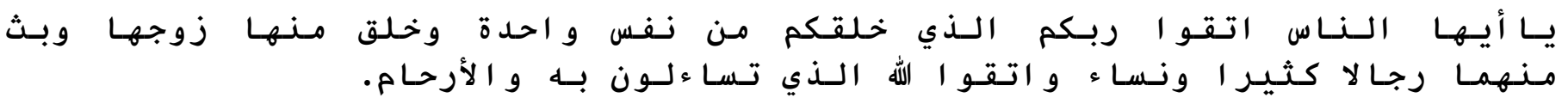

"O mankind! Fear your God who created you from a single soul and then created its mate, and from these two creatures spread countless men and women. So, fear Allah for Whose sake you ask needs from one another." (Quran, 4:1)

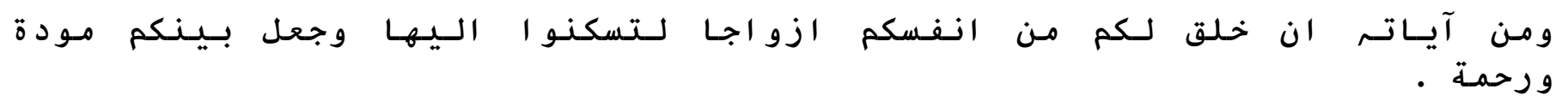

"And it is from His signs that He created your mates for you of your kind so that you sake peace from them, and He made between you love and mercy." Quran,30:21)

Above mentioned verse depicted creation of man and woman, and marital relations with love, tranquility and mercy have been flagged as signs of God. The Quranic injunctions take into account gender equity and psychological differences between males and females. No kind of gender becomes a family partner except human being as prevailing in west thoughts( kabir '2002, Qutb, 2015). Both genders having same kind resulted love and mercy. No doubt that distinct kind of genders have not such strong love. God Almighty made marriage as sign of love and mercy for human being (Al-Su'ūd. 2015). This text indicated marriage and generation named as love and mercy (Kashaf, 2017). As the Qur'an referred woman as source of tranquility for man and same time it considers man's responsibility for woman. Men are cited as "protector and maintainer" of her women.

Muslim society has significant place for its basic unit, family institution. About one third legal injunctions of the Qur'an deals with family institution and its proper regulation. A Muslim family is referred to extended family not an atomistic family consisting of the parents and children only. Generally, it has three or four generations under its umbrella as Islamic inheritance law declared them integral part of the basic family structure and not just circumstantial position. 


\section{Family Establishing Contract}

Muslim Family institution is constituted through the marriage for which used the term Nikah which means 'aqd' (contract). It is come to use in Qur'an more than twenty times. Islamic marriage concept forbids all forms of sex relationships other it as pre or extra matrimonial relations etc. marital relationship not exist mere momentary or ephemeral pleasure but must proceed in responsible and stable manner via marriage. Needless to say, evil person has tilts to vile and footprints on society so must be avoided them. The Holy verse is revealed as;

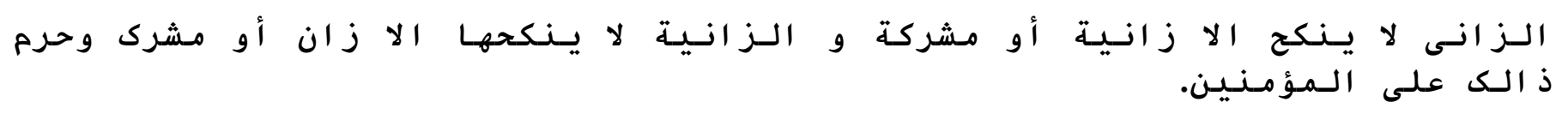

“An adulterer doesn't marry but an adulteress or a polytheist, and no pious man marry an adulteress but only an adulterer or a polytheist. And this act is forbidden to the Muslims.” (Quran, 24:3)

In another verse characteristics of Muslim individual were mentioned and impeded the marital relationship as revelation is;

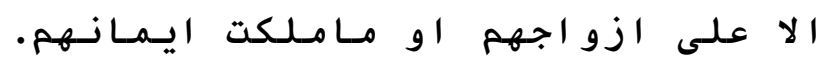

"Except from their wives or slave-girl who is the possession of them". (Quran, 23:6)

Marriage has more importance to stable family institution and society life. Even war occupied women were given dignity with marriage. So such relationship has permanency and enduring each other with hope to live together and play a sustained role in society instead of temporary sex satisfaction.

In Qur'an, marriage has been particularly described as Mithaqan ghaliza (strong covenant). The Qur'anic verse states as;

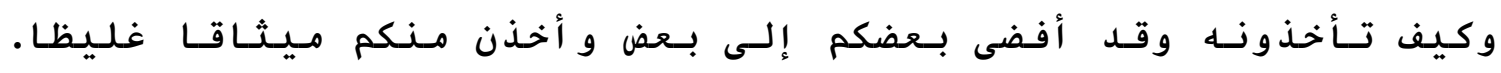

"And how can you get it back whilst you have had marital tie-up with each-other and they have also taken strong promise from you." (Quran, 4:21)

This text depicted sturdy nature of marriage contract. This contract has weighty and potent prepositions (offer and acceptance). Similar to other civil contracts, the marriage convent has foots as its validity depends on capacity of the contracting parties, which is majority and discretion. Moreover mutual consent and public declaration of the marriage contract are its essentials. No particular ceremony is required by Sharia'h but only preposition of offer and acceptance is enough directly or via agent. For this matrimonial contract, a dower is paid to the bride which is sole and exclusive to her as well as at least two witnesses are required. Islamic marriage is for entire span of life but dissolving power rests with both partners. Nevertheless, marriage is a social and sacred contract leading to a set of relationships and generates mutual responsibility. However, such contract is not irrevocable sacramentally.

Islam took initiatives to elevate the position of women in society and such as practices to inherit women was forbidden and validity of marriage was based on consent of both spouses explicitly. The Qur'an says; 
Review of Education, Administration and Law (REAL)
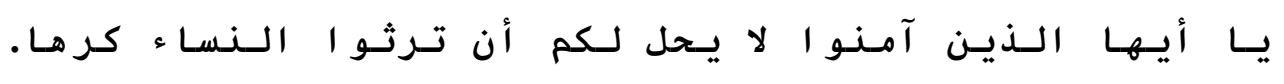

“O believers, it is unlawful for you to get women by force as heirs” (Quran, 4:19).

\subsection{Marriage Relevant Matters}

\subsubsection{Dower}

Islam elevated the women status from inferior to superior and introduced special rights for them. It instructed mandatory dower amount for women dignity and didn't prescribe its maximum amount but left upon marring spouses.(AL-Tabri) This dower amount is exclusively women property and she is the owner and custodian of it. She can use it freely and waive off for husband also without any coercion.( Fath ul Qadeer,) The Quran said;

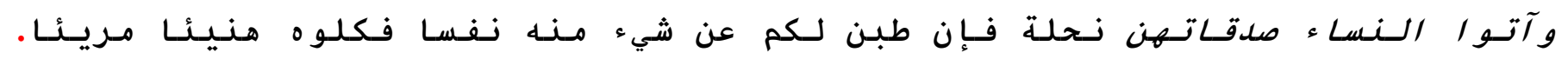

"And pay women their dower amount happily. Then if they waive off for you some out of it with pleasure, you may spend it as u wish.” Quran, 4:4)

Another text revealed as;

"Pay the women their specified amount of dower." Quran, 4:24)

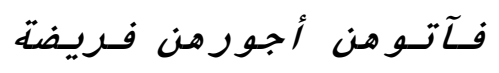

Islam declared the dower a mandatory duty for the husband. Islam introduced effective motions for women empowerment and financial position particularly. .( Fath ul Qadeer,) The holy verse stated;

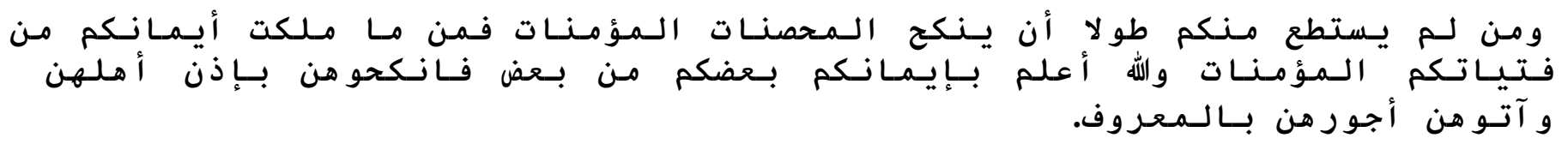

“And who one of you can't marry to free believing women, may marry believing slave-girls who are your possession. And Allah knows the best your belief. So, marry them with the permission of their supervisors." Quran, 4:25)

This text also describes the capability of marriage and indicating that free Muslim woman has preference on Muslim slave-girl. Islam placed the dower for the slave-girl also empowering her with dignity and expounded the role of guardian. The amount of dower must be a reasonable against her dignity instead of degrading. (Al-Baghawi), Moreover, its payment also should be a respectable way.

\subsubsection{Maintenance}

Islam talks about rights and duties both for every citizen. It significantly puts more intention on women and children etc. The dower and maintenance must be rationale amount. Islam didn't limit it but prescribed a principle that everyone should pay according to his social status. It is very unreliable custom to pay a worthless amount to wife or push her to spend it on mosque or charity etc. The Quran expounded that rich and poor should pay according to their status not otherwise.( Al-Tabarī, 20og) The Quran said;

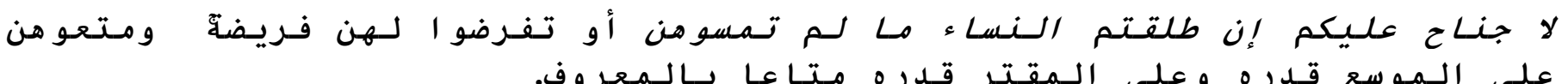


"No sin will be on you if you divorce women even before touching them or fixing their dower. Provide for them appropriately, it is mandatory for rich against his means and for the poor against his status. (Quran, 2:236)

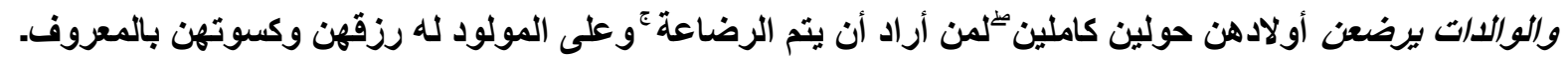

"And the mothers shall suckle their babies for two years. It is instruction for whom who wishes to fulfill suckling duration. And against usage, food and clothes of the mother on the father" (Quran, 2:233)

Here, suckling period for a baby is mentioned. All expenses of feeding mother is on shoulder of the father according to the prevailing custom or his social status ( Kathir ,2002).

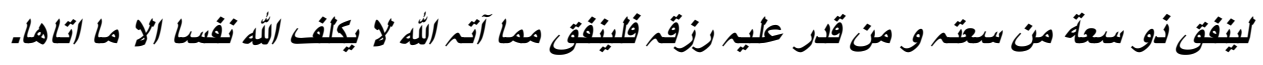

"Affluent should spend against his means. And whoever have substance scarcely, spend out of which Allah is granted him. He doesn't impose anyone beyond capacity. Allah ll soon bring easiness after hardship.”(Quran, 65:7)

The maintenance has no minimum or maximum amount but upon to his means and status. God doesn't impose high conditions but according to having one. (Al-Ṭabarī 2009)

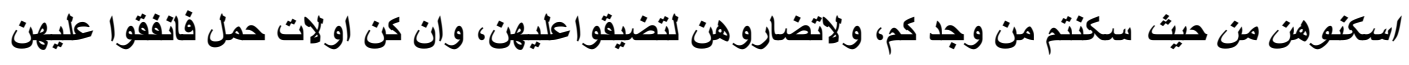

"keep the divorced women where you live against your means, And don't harm them as intolerable for them. If they are pregnant, spend them..." (Quran,65:6)

This verse imposed the maintenance on husband and impeded from any type of harm or indifference. In all circumstances, wife's maintenance is the husband's obligation. A divorced woman also deserves in pregnancy or suckling mood. No doubt other than mother, a lady may suckle the child but without cause mom can’t deprive this right. ( Al-Ṭabarī , 2009)

A divorced woman simultaneously deserves maintenance during the waiting period but afterwards she also has with mutual consent or court order.( OLFR,1917) The test indicated;

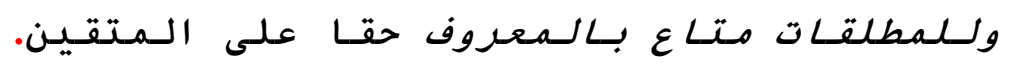

"And for divorced women, must be some maintenance against fairness. It is compulsion for the pious" (Quran,2:241)

Islam teaches to treat women with kindness and nice way for the purpose of strong family. It includes payment of dower, maintenance and all other rights fulfilment. It directs to refrain from all mental, psychological, financial and physical tortures. Al-Jassas ,2009) On family life, the text is;

“Spend life with them pleasantly nicely)." (Quran,4:19)

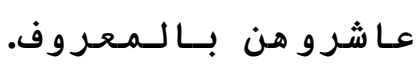

\section{Divorce}

In case of shackle of marriage contract, rupturing its objectives and having irretrievably broken down. A reconciliation to be tried by family arbitration to restore it before final dissolution. Primarily, 
Marriage is a relationship between the spouses, in fact, it enjoins two families, and even more. So parents or other members of the family play a much more positive role in it. In failure, separation is allowed and Re-marriage is permitted even encouraged. Unlike Hinduism, here is no stigma with Remarriage or to marry a divorced or a widower.

\subsection{Pre-occurrence Steps}

Islam provides complete guide for matrimonial life. For rebellious atmosphere, there are indicated some steps first to advise, to separate beds temporarily and as last some aggressive position. It must be clear that this aggression has no way like war but negotiating intention.( Ibn 'Ashur, 1984) A mom also adopts aggressive mood for her baby but it's totally fabricated not serious. When someone say sorry and come back, then no way to tease or punish her. (Al-Baghawi, 2019) The divine instruction is;

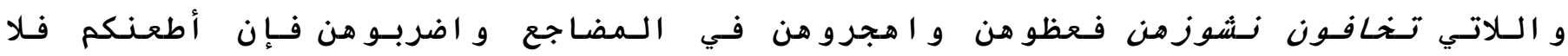

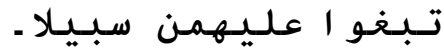

"And those you fear rebellious conduct, advise them and leave them alone in their beds, and turn away from them, striking a temporary separation. If they cooperate with you, don't seek any action against them" Quran, 4:34)

\subsection{Mediatory Council Formation}

When quarrel between spouses trembles this sacred intuition, the husband should not hurry for divorce nor wife ask for khula but arbitration should play its role. The arbitration must include members from both families so that they feel secured and trusted for sharing the matter. Moreover the relatives have close knowledge about family matters of each other. Family members should also stand for enjoining family within the boundaries of God (Ibn 'Ashur , 1984).

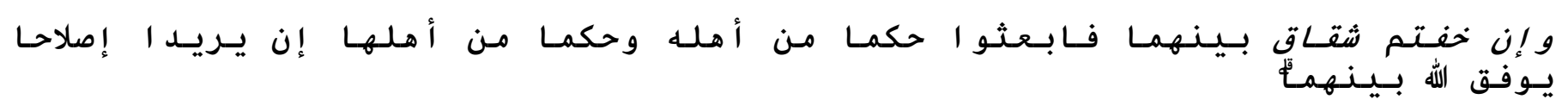

"And if you see fear to breach between them, appoint arbitrators from husband and wife's families. If they both resolve the issue, Allah will create harmony between them." Quran, 4:35)

Islam desires to save and strong family institution on every cost. Whenever spouses fear to break down the family, then should reconcile their attitudes. Family require scarification so every member should care each other instead of claiming one. (Qurtabi,2012)

At another text said;

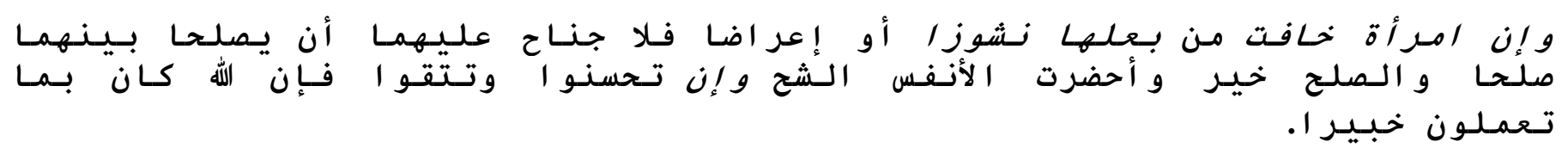

"If a woman fears maltreatment or indifference of her husband, no harm to reconcile on some appropriate accord and the reconciliation is the better. It is human nature been made self-seeking but if you exercise benevolence and guard yourselves against evil, Allah is surely Well aware of whatever you do" (Quran, 4:128). 


\subsection{Reconciliation after Divorce}

When all possibilities end and divorce is pronounced then Quran stated as;

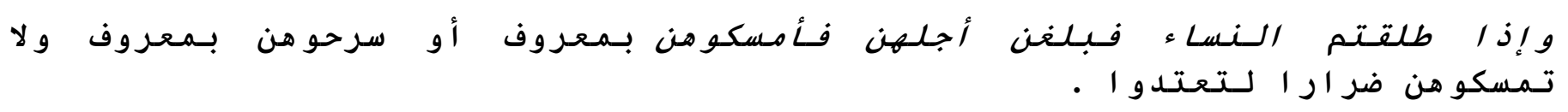

"And when you divorce the woman and completed the waiting duration, then either retain or release them gracefully. But don't retain to hurt (Quran, 2:231).

Islam teaches to maintain family with love and peace even after divorce either revoke it or release without searching any harm way. This text holds separately the word gracefulness for retaining or releasing each one. It is prohibited to revoke with harm intentions. To hurt women without just cause, is a challenge to God. Islam protects women and prevent any type of excess or tease.( Baghawi, 2019 Even after divorce, Islam inspires to re-join marital bond as revealed;

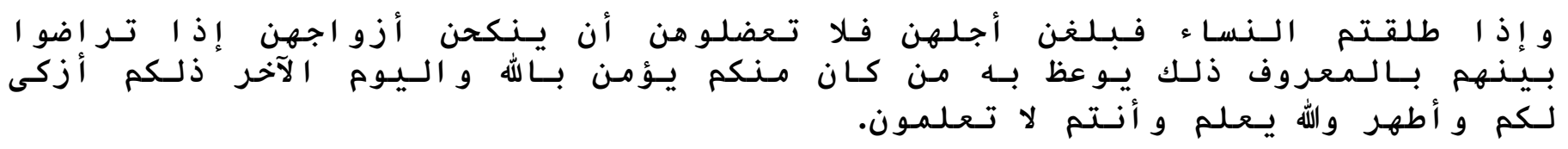

"And when you divorce women and completed the waiting period, don't prevent them from remarriage with husbands when they mutually agreed. It is right direction for believers and the most pure and clean for you" (Quran, 2:232).

After pronouncement of two divorce, if they desire to re-marry after waiting period should not make any hurdle. It is rationale that first marital bond is much approachable than new phase. But they have practiced thrice time divorce and no way to revoke it. After this all, Islam again gives opportunity to re-marry but after divorce from second one. These all matters are referred to the boundaries prescribed by the God so must not violate them. The details are revealed;

$$
\text { الـطلاق مـرتـان فـإمسـاك بـمـعـروف أو تـسريـح بـإحسـان }
$$

"Divorce is twice only. After that either retain with hounr or release her with act of kind" (Quran, 2:229).

The other text mentioned as;

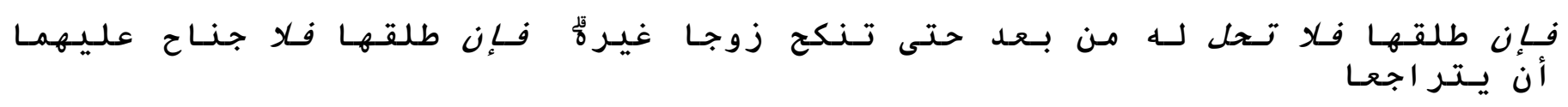

"If he divorces (third time), she 11 not for him lawfully unless she marries some other than him. But if he also divorces her, now no sin on both to return as marital relationship.”(Quran, 2:230)

\subsection{Witnesses}

Marriage is a social and public contract so its origin and end require public knowledge. It is much saving from any type of accusation or blame. Moreover, to appoint two witness on divorce matters will cause reduce the ratio of divorce rationally. It is advised as;

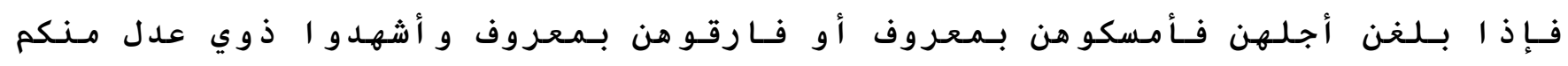


"When they close to end their appointed term, retain them kindly or separate with nicely and take two pious witnesses amongst you.”(Quran, 65:2)

\subsection{Waiting Period}

Islam placed the injunctions with logic not otherwise. It is categorical division for waiting period with wisdom. Before the consummation of marriage, a divorce woman has no need to wait a specified period. Here, Islam again protected women dignity and asked to pay something to her with kindness

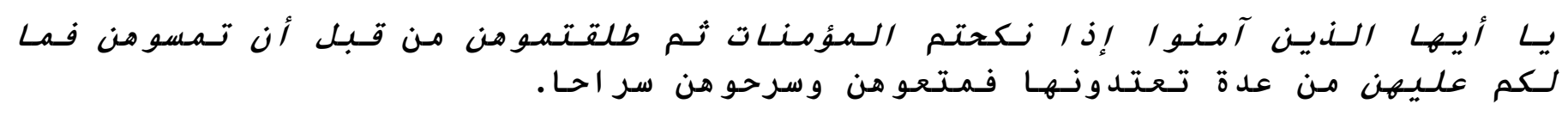

"O believers, no waiting duration for women when you divorce them before touching them so give them something and release nicely.” (Quran, 33:49)

Likewise another text justified it for a consummated woman. Islam more cares of genetical lines and prescribed some waiting period to judge it. For a divorce woman, three moths is a waiting period and not fair for her to secret what is in her womb. During this waiting period, husband may revoke it with good intention. The statement is;

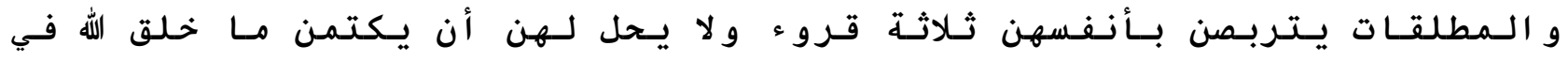 أرحـامهن.}

"And three menstrual cycles are for divorced women, and it is unlawful to conceal what Allah may have created in their wombs." (Quran, 2:228)

For a widow waiting period is four months and ten days. This is prescribed for womb's clearance as well as symbol of death's sorrow. The divine writing is,

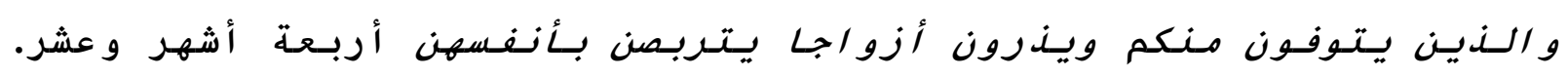

"And whoever amongst you die and leave widows behind, shall wait for four months and ten days. (Quran, 2:234)

For women having not sign of menstruation, waiting period is rationalized by three months. It is stated as;

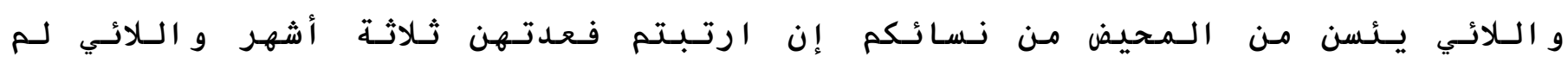 يـحضن}

"And women of you having no hope of menstruation, three months is prescribed time for them, and also for them who have not yet menstruated." (Quran, 65:4)

A pregnant woman has to wait till birth of the child. As the Quran said;

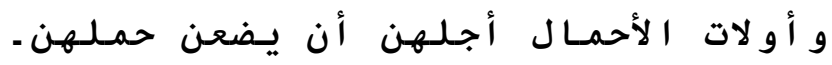

"Birth of the child is the term for pregnant women." (Quran, 65:4) 


\section{Conclusion and Recommendations}

Family has the highest regard in social institutions in human civilizations. Prosperity of society is relied on this fundamental brick. Islam prescribed distinct approach regarding family institution. It secures husband and wife relationship through marriage eligibility, gender equality, dower and maintenance matters. In case of separation, it prescribed a complete way to dissolve this tie-up. To compete contemporary child marriage, forced marriage and high divorce ratio, it is time to take guidance from the Quranic textual study. Before enter to marriage, spouses must hold a reasonable age for marriage which is maturity of body and mind. Physical and psychological disturbed spouse cannot sustain family burden and lead to suicide. Here are some recommendations;

- Age and child marriage: - Although no pecuniary provisions may not introduced for child marriage but government may achieve the task through the policy of encouragement not punishment. Government should encourage marriages after maturity of age at least 25 years and discourage child marriages. This figure is determined as practice of the Holy Prophet.

- Consent and forced marriage: - It is need to assure the consent of spouses particularly girl's consent at the time of Nikah. Government may proclaim mandatory consent declaration before judge particularly in case of child marriage to bar the forced marriages. Here, penal clause may also passed.

- Equality of spouses: - Islam placed both spouses with equal rights and human dignity recognizing gender equality. It ensures equal status of husband and wife in society in various aspects. Government should encourage equal status of couples and make part of the Nikah Farm. It is time to note significantly husband's monetary position as well as their academician status for happy survival of the marital life.

- Dower and Maintenance: - Non-payment of dower and maintenance is big practice of our society. Government should assure these payments to secure the women rights. Here can be introduced a proper receipt performa ensuring payments. Likewise, dower, maintenance or heritance may not be waive off until transferred to the wife.

- Divorce and Mediation Council: - Government should enrolled social and religious scholars as members of the local councils. Religious scholars can play a key role as alternative dispute resolving councils also.

- Witness: - It is need to follow the opinion declaring mandatory witness for effecting divorce. It will reduce the divorce ratio and secure the family institution.

- Triple Divorce: - Government must legislate penal clause for triple divorce according to the recommendation of the council of Islamic ideology.

- Waiting period: - After divorce, some reasonable maintenance amount according to social status should be paid. It may be imposed through the court or by discretion of spouses.

\section{References}

Abi Hatim, Abu Muhammad Abderrahman, TAFSIR AL-QURAN AL-'ADHIM - IBN ABI HATIM, (Beirut: Al Maktaba Al Assrya, 2003)vol:3, p.909

Abū al-Sa'ūd, Mulạmmad ibn Mulạmmad, irshād al-'aql al-salīm ilá mazāyā al-Kitāb al-Karīm : Tafsīr Abī al-Su'ūd (Beirut Dār al-Kutub al-'Ilmīyah, 1999), vol:7, p. 56.

Al-Baghawi, , Abu Muhammad Al-Husayn ibn Mas'ud al-Baghawi, Tafsir Al-Baghawi Al-Musamma Ma'alim Al-Tanzil ,( Beirut: Dar Ibn Hazm, 2004)vol: 1,p.275,vol: 2,p.207.

Al-Baydawi, Abdullah Ibn 'Umar Ibn Muhammad Ibn 'Ali, Anwar al-Tanzil wa-Asrar al-Ta'wil,(Beirut: Dar Ihya al-Turath al-Arabi , 2015), vol:4,p.204, vol:2, p. 67, 
Al-I\$̣ahānī, Abu 'l-|̣̣sim al-|̛̣̂sayn b. Mulạmmad b. al-Mufạ̣ll, Mufradat-ul-Quran, (Damascus: Dar alKalam, 2014).

Al-Jassas, Abu Bakr Ahmad bin Ali al-Razi, Ahkam al-Quran, (Beirut: Dar Kotob al-Ilmiyah, 2019),vol: 3,p.47

Al-Māwardī, Abū al-kạlsan 'Alī ibn Mulạmmad ibn lậbīb al-Bașī, Min Rawai' al-Tafasir Al-Nukat wal 'Uyuun Tafsir Al-Mawardi, (Beirut: Dar al-Kutub al-'Ilmiyya, 2010), p. 6:44.

Al-Razi, Fakhr Al-din Muhammad bin Umar bin Hasan, Al-Tafsir Al-Kabir Aw Mafatih al-Ghaib (Beirut: Dar al-Kutub al-'Ilmiyya, 2018) p. 97.

Al-Shawkani, Imam Muhammad bin Ali bin Muhammad, Fath ul Qadeer al-Jame' Bynai al-Riwaya wal Diraya fi Ilm-al-Tafseer,(Qahira: Dar Al Maarifa, 2013) p.927.

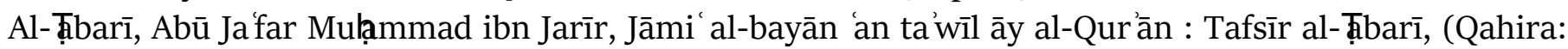
Dar Ibn e Hazm, 2009), vol:1,p.559, vol: 5,p.121,vol: 8,p.192

Al-Zamakhshari, Abi Al-Qasim Muhammad bin Umar, Tafsir al-Kashaf An Haqa'iq al-Tanzil Wa Uyun Al-Aqawil Fi Wojuh Al-Ta'wil, (Beirut: Dar-ul-Ma'rifah, 2002),vol: 4, p. 571.

Attari, Mufti Muhammad Qasim, Sirat ul Jinan fi Tadseer Al-Quran, (Karachi: Maktaba-tul-Madina, 2015).

Daniel Bell, The Coming of Post-Industrial Society (London: Heinemann, 1974)

Dr. Mahmood Ahmed Ghazi, Muhazirat e Fiqh , (Lahore: Al-Faisal Publisher, 2003), p.236-72.

Fath ul qader,1:282, 4: 19, 1:267,

http://Gorji , Abolghasem "Islam Entry" The Great Islamic Encyclopedia. Ed. Kazem Musavi Bojnourdi.Tehran: The Center of Great Islamic Encyclopaedia , 1989-, V.8 ,pp.415 _ 416

https://www.erfan.ir/urdu/50173.html

Ibn 'Ashur, Muhammad Tahir, Tafsīr al-Taḥ̣īr wa-al-tanwīr al-ma'rūf bi-Tafsīr Ibn 'Āshūr (Tunis :Dar Souhnoun, 1984) vol:5,p. 38, 45

Kathir , 'Imad Ad-Din Isma'il bin 'Umar, Tafsīr al-Qur'ān al- 'Ạ̄̄mm: Ibn e Kaseer,( Riyadh : Darussalam , 2000),vol:1,p.633, vol:2,p.427.

Khalid Rahman, Saleem Mansour Khalid, Woman,Family and Our Society: Problems and Way-out, (Islamabad: Institute of Policy Studies, 2007), p.12-1324-25.

OLFR,1917

Pitrim A. Sorokin, Social Philosophies of an Age of Crisis, (London; Adam \& Charles Black, 1950).

Qurtabi, Muhammad bin Ahmad, Al-Jami li-Ahkam al-Qur'an, (Beirut: Risala, 2006),vol: 5,p.345

Qutb, Sayyid Ibrahim Husayn Shadhili, Fị ̣̣̣āl al-qur'ān, (UK: Islamic Foundation, 2005),p. 3334.

Rovert L. Heilbroner, "The Human Prospect", The New York Review of Books, January24, 1974

See Syed Amir Ali. Mohammedan law Lahore. All Pakistan Legal Decisions. 1965 Vol. II, p.44-48

The Quran 2:228, 229, 230, 231, 232,233, 234,236, 24, 4:4, 14, 21,24, 25, 34, 3, :35, 128,4:, 23:6, 20:132,

24: 3, 30: 21, 33:49, 49:13, 53: 45, , 65:2, 4, 6,7, 66:6,

Usmani, Mufti Muhammad aqi, Aasan Tarjuma e Quran, (Karachi: Ma'ariful Qur'an, 2012). 